\title{
Protein Polybromo-1
}

National Cancer Institute

\section{Source}

National Cancer Institute. Protein Polybromo-1. NCI Thesaurus. Code C95440.

Protein polybromo-1 (1689 aa, $193 \mathrm{kDa}$ ) is encoded by the human PBRM1 gene. This protein plays a role in the modulation of both gene transcription and chromatin modeling. 